\title{
Nonindigenous Species Introductions on Coral Reefs: A Need for Information ${ }^{1}$
}

\author{
S. L. Coles ${ }^{2,3}$ and L. G. Eldredge $e^{2}$
}

\begin{abstract}
Nonindigenous species invasions have caused disruptions of native communities and detrimental economic impacts to fisheries in many temperate marine areas. However, comparatively little information exists for tropical regions, and even less is known about occurrences and impacts of nonindigenous species on coral reefs. Studies in the Tropics to date have mostly been limited to surveys in harbors and ports where corals and reef organisms are usually missing or rare and environmental conditions are usually quite different from those found on coral reefs. The few studies available for coral reefs suggest that nonindigenous species are thus far a relatively minor component of the total biota, but some species, especially introduced red algae, can be invasive and dominate reef areas. With limited information available, there is a need for studies of the occurrence and impacts of nonindigenous species that are focused on coral reef environments. This review summarizes the information for nonindigenous species from harbors, embayments, and coral reef surveys in the tropical Pacific and outlines procedures for studies to detect species introductions.
\end{abstract}

The INTRODUCtion of nonnative marine algae, invertebrates, and fishes (hereinafter called nonindigenous species) into receptor areas where they may proliferate uncontrolled by predators or other controlling factors has become recognized as a significant disturbance to balanced native ecosystems. Nonindigenous species can rapidly monopolize energy resources, act as voracious predators, overcome endemic species, or transmit parasites and diseases that can be passed to humans through the food chain or direct exposure. Because of the serious consequences that can result from nonindigenous introductions, marine species invasions have been ranked among the most serious potential sources of stress to marine ecosystems (Carlton 1993).

${ }^{1}$ Paper presented at the Ninth International Coral Reef Symposium, Bali, Indonesia, 27 October 2000. Manuscript accepted 5 September 2001.

2 Bishop Museum, 1525 Bernice Street, Honolulu, Hawai'i 96817.

${ }^{3}$ E-mail: sicoles@bishopmuseum.org

Pacific Science (2002), vol. 56, no. 2:191-209

(C) 2002 by University of Hawaici Press.

All rights reserved
In the last century, and more especially during the last two decades, human-related redistributions of marine shallow-water organisms have become more frequent and increasingly important in their impacts on native communities. Since the 1970 s, a substantial increase in instances of exotic species invasion has occurred in harbors, ports, and other coastal ecosystems in temperate regions around the world (see Carlton 1985, Carlton and Geller 1993, Ruiz et al. 1997 for reviews). Such introductions have produced serious environmental and economic impacts at various locations. Table 1 summarizes a few of the more famous examples of marine bioinvasions that have disrupted temperate marine areas. These invasions demonstrate similar characteristics in having become more pervasive during the 1980 s and 1990 s and having accurred throughout many of the world's oceans. Although increased movement of larval organisms in cargo ships' ballast water is usually attributed to be the principal cause of these increases in bioinvasions (Carlton 1985, Chu et al. 1997, Smith et al. 1999, Wonham et al. 2000), other factors such as release of imported exotic aquarium or aquaculture organisms or vessel hull fouling may also have made important contributions to non- 
TABLE 1

Marine Bioinvasions in Temperate Regions

\begin{tabular}{|c|c|c|c|c|c|}
\hline Species & Common Name & $\begin{array}{l}\text { Area/Date of } \\
\text { Introduction }\end{array}$ & $\begin{array}{c}\text { Origin or } \\
\text { Previous Range }\end{array}$ & Impacts & References \\
\hline $\begin{array}{l}\text { Caulerpa } \\
\text { taxifolia }\end{array}$ & Fern alga & $\begin{array}{l}\text { Mediterranean, } \\
1984\end{array}$ & Tropical oceans & $\begin{array}{l}\text { Substrata } \\
\text { monopolization }\end{array}$ & $\begin{array}{l}\text { Bourdouresque et al. } \\
\text { 1992, Bellan-Santini } \\
\text { et al. 1996, Meinesz } \\
1999\end{array}$ \\
\hline $\begin{array}{l}\text { Mnemiopsis } \\
\quad \text { leidyi }\end{array}$ & $\begin{array}{l}\text { American comb } \\
\text { jelly }\end{array}$ & Black Sea, 1980 & $\begin{array}{l}\text { Western } \\
\text { Atlantic }\end{array}$ & $\begin{array}{l}\text { Predation on } \\
\text { anchovies }\end{array}$ & $\begin{array}{l}\text { Vinogradov et al. 1989, } \\
\text { Shushkina et al. } \\
\text { 1990, Mutlu } 1999\end{array}$ \\
\hline $\begin{array}{l}\text { Carcinus } \\
\text { meanas }\end{array}$ & $\begin{array}{l}\text { European green } \\
\text { crab }\end{array}$ & $\begin{array}{l}\text { San Francisco } \\
\text { Bay, } 1990 \text { to } \\
\text { Puget Sound, } \\
1999\end{array}$ & $\begin{array}{l}\text { Europe-NW } \\
\text { Africa; } \\
\text { western } \\
\text { Atlantic }\end{array}$ & $\begin{array}{l}\text { Predation on } \\
\text { shellfish }\end{array}$ & $\begin{array}{l}\text { Behrens Yamada et al. } \\
\text { 1999, Cohen 1999, } \\
\text { Grosholz and Rurz } \\
1999\end{array}$ \\
\hline $\begin{array}{l}\text { Hemigrapsus } \\
\text { sanguineus }\end{array}$ & $\begin{array}{l}\text { Pacific grapsid } \\
\quad \text { crab }\end{array}$ & $\begin{array}{l}\text { New Jersey, } \\
1988\end{array}$ & $\begin{array}{l}\text { Western Pacific } \\
\text { (Japan) }\end{array}$ & $\begin{array}{l}\text { Competition } \\
\text { with native } \\
\text { species }\end{array}$ & $\begin{array}{l}\text { McDermott 1991, 1999, } \\
\text { Larson et al. 1999, } \\
\text { Seeley } 1999\end{array}$ \\
\hline $\begin{array}{c}\text { Potamocorbula } \\
\text { amurensis }\end{array}$ & Asian clam & $\begin{array}{c}\text { San Francisco } \\
\text { Bay, } 1986\end{array}$ & $\begin{array}{l}\text { China, Japan, } \\
\text { Korea }\end{array}$ & $\begin{array}{l}\text { Pipe clogging, } \\
\text { resource } \\
\text { monopolization }\end{array}$ & $\begin{array}{l}\text { Carlton et al. } 1990, \\
\text { Thompson and } \\
\text { Luoma } 1999\end{array}$ \\
\hline $\begin{array}{l}\text { Asterias } \\
\quad \text { amurensis }\end{array}$ & Pacific seastar & Tasmania, 1992 & $\begin{array}{l}\text { Bering Sea, } \\
\text { Japan-Russia }\end{array}$ & $\begin{array}{l}\text { Predation on } \\
\text { shellfish }\end{array}$ & $\begin{array}{l}\text { Buttermore et al. } 1994, \\
\text { Rodriguez et al. } 1999\end{array}$ \\
\hline
\end{tabular}

indigenous species proliferation (Godwin and Eldredge 2001).

\section{AVAILABLE INFORMATION FOR} TROPICAL AREAS

Most of the available information for marine and brackish-water introductions has been limited to observations and studies in temperate regions (e.g., Carlton et al. 1990, Shushkina et al. 1990, McDermott 1991, Bourdouresque et al. 1992, Buttermore et al. 1994, Cohen et al. 1995, Lambert and Lambert 1998). These surveys of resident biota, focusing on nonindigenous species, have been concentrated in areas of substantial shipping activity most likely to receive species introductions from ballast water discharge or hull fouling. Also, the receiving water and surfaces in harbors and ports may promote the survival and growth of organisms that have been transported from ports where a vessel began its voyage. Harbors, ports, and embayments are therefore the most likely areas to observe outbreaks of nonindigenous species, but successful invaders may spread rapidly from these areas of introduction.
Knowledge of aquatic nonindigenous species in the Tropics principally has been based upon literature studies that have summarized introductions of organisms primarily for aquaculture purposes in the Pacific. Most of the available information pertains to freshwater systems. The first major review was by Walford and Wicklund (1973), who described a case history of the Hawaiian Islands based on a review by Brock (1960). Maciolek (1984) reviewed the fishes introduced to the tropical Pacific, to which Randall (1987) added new information for Hawaiian fishes. Uwate et al. (1984) conducted a country-by-country review of aquaculture activities in the tropical Pacific. Andrews (1985) provided information on a wide range of aquatic animals introduced to Fiji, and West and Glucksman (1976), Allen (1991), and Werry (1998) described fish introductions for New Guinea. Munro (1993) described aquaculture development with respect to environmental issues in the Pacific. Introductions to coral reefs in the tropical Pacific were reported by Eldredge (1987), who also reviewed commercially significant organisms imported to Pacific islands (Eldredge 1994) and freshwater fishes, 
TABLE 2

Tropical Nonindigenous Species Surveys

\begin{tabular}{|c|c|c|c|}
\hline Location & Date & Biota Surveyed & Source \\
\hline \multicolumn{4}{|l|}{ Ports and harbors } \\
\hline Hawai'i: Pearl Harbor & 1996 & Algae, invertebrates, fish & Coles et al. $1997,1999 a$ \\
\hline $\begin{array}{l}\text { Hawai'i: O'ahu south and west } \\
\text { shore harbors }\end{array}$ & $1997-1998$ & Algae, invertebrates, fish & Coles et al. $1999 b$ \\
\hline Guam: Apra Harbor & 1997 & Invertebrates ${ }^{a}$ & Paulay et al., unpubl. data \\
\hline Australia: 12 Queensland ports & 1997 & (Literature review) & Hilliard et al. 1997 \\
\hline Australia: Hay Point Port & 1997 & Algae, invertebrates, fish & Hewitt et al. 1998 \\
\hline $\begin{array}{l}\text { Australia: Mourilyan Harbour } \\
\text { and Abbot Point }\end{array}$ & 1999 & Algae, invertebrates, fish & Hoedt et al. 2000 \\
\hline Australia: Lucinda Port & 1999 & Algae, invertebrates, fish & Hoedt et al. 2001 \\
\hline \multicolumn{4}{|l|}{ Reef areas } \\
\hline Hawaici: Kaho'olawe & 1998 & Algae, invertebrates & Coles et al. 1998 \\
\hline Hawaici: Midway & 1997 & Algae, invertebrates, fish & DeFelice et al. 1998 \\
\hline Johnston Atoll & 2000 & Algae, invertebrates, fish & Coles et al. 2001 \\
\hline Guam & $1997-1999$ & Invertebrates & Paulay et al. in press \\
\hline Hawai'i: Kāne‘ohe Bay & $1999-2000$ & Algae, invertebrates, fish & In progress \\
\hline
\end{tabular}

${ }^{a}$ Includes only sponges, echinoderms, and ascidians.

amphibians, and crustacean introductions throughout the tropical Pacific (Eldredge 2000). One important and widely introduced group - the tilapia - was the topic of a single review by Nelson and Eldredge (1991). Russell (1992) summarized the introduction of 17 taxa of marine algae to Hawai $i$, some of which have become invasive and nuisance. J. T. Carlton and L.G.E. (unpubl. data) have reviewed the marine and brackish-water invertebrates of Hawai' $i$ and determined approximately 343 species to be demonstrably or potentially nonindigenous, about $7 \%$ of the approximate 5000 marine species estimated for Hawai'i (Allison et al. 1995).

Only recently has site-specific information on nonindigenous species introductions become available for tropical areas, and these results are based solely in the Pacific, mostly for harbors on O'ahu, Hawai'i (Coles et al. 1997, 1999a,b); in Guam (G. Paulay, L. Kirkendale, G. Lambert, and J. Starmer, unpubl. data); and ports in North Queensland, Australia (Hilliard et al. 1997, Hewitt et al. 1998, Hoedt et al. 2000, 2001) (Table 2). Surveys emphasizing detection of nonindigenous species on coral reefs have been completed for only three locations: at Kaho'olawe in the main Hawaiian Islands (Coles et al. 1998), at Midway Atoll at the western end of the Hawaiian chain (DeFelice et al. 1998), and at Johnston Atoll (Coles et al. 2001). Studies are in progress to make similar determinations for the coral reef environments of Kanne'ohe Bay and Waikīkī (S.L.C., R. C. DeFelice, and L.G.E., unpubl. data), and for French Frigate Shoals, Northwestern Hawaiian Islands, and proposed for the harbors of Fiji and Nauru.

The findings for the completed studies are summarized in Table 3 . The results include species designated as nonindigenous and cryptogenic (i.e., neither demonstrably native nor introduced sensu Carlton [1996]), and these are compared with the total numbers of species identified in each study. Nonindigenous and cryptogenic status for the Hawai'i studies were based on information presented in $\mathrm{J}$. T. Carlton and L.G.E. (unpubl. data). The greatest proportion of nonindigenous and cryptogenic species occurred in the harbors of O'ahu, which included Pearl Harbor (Figure 1a; Coles et al. 1997, 1999a) and the five other harbors of O'ahu's south and west shores (Figure1b-d; Coles et al. 1999b). These areas receive virtually the entire shipping, fishing, and other oceangoing traffic for $\mathrm{O}^{\prime}$ ahu and much of the Hawaiian Islands. Both studies (Table 3) found about 100 non- 
TABLE 3

Numbers of Marine Nonindigenous, Cryptogenic, and Total Species Determined from Hawai'i, Johnston Atoll, Guam, and Australian Surveys

\begin{tabular}{|c|c|c|c|c|c|}
\hline Location & $\begin{array}{l}\text { Nonindigenous } \\
\text { (N) }\end{array}$ & $\begin{array}{l}\text { Cryptogenic } \\
\text { (C) }\end{array}$ & $\begin{array}{l}\text { Total } \\
\mathrm{N}+\mathrm{C}\end{array}$ & $\begin{array}{c}\text { Total } \\
\text { Species }\end{array}$ & $\begin{array}{c}\% \\
\mathrm{~N}+\mathrm{C}\end{array}$ \\
\hline \multicolumn{6}{|l|}{ Hawai'i } \\
\hline O'ahu: Pearl Harbor & 69 & 26 & 95 & 419 & 23.0 \\
\hline O'ahu: $S$ and $W$ shores & 73 & 27 & 100 & 585 & 17.0 \\
\hline Midway & 4 & 0 & 4 & 444 & 1.5 \\
\hline Kaho'olawe & 3 & 0 & 3 & 298 & 1.0 \\
\hline Johnston Atoll & 5 & 5 & 10 & 668 & 1.5 \\
\hline \multicolumn{6}{|l|}{ Guam } \\
\hline Apra Harbor & $27^{a}$ & $29^{a}$ & $46^{a}$ & 682 & 6.7 \\
\hline Islandwide & 40 & 40 & 80 & 4,635 & 1.7 \\
\hline \multicolumn{6}{|l|}{ Australia } \\
\hline 12 Queensland ports & 15 & 15 & 30 & - & - \\
\hline Hay Point Port & 9 & 3 & 12 & 506 & 2.4 \\
\hline Mourilyan Harbour & 2 & 2 & 4 & 401 & 1.0 \\
\hline Abbot Point Port & 0 & 5 & 5 & 593 & 0.8 \\
\hline Lucinda Port & 2 & 9 & 11 & 480 & 2.3 \\
\hline
\end{tabular}

${ }^{a}$ Includes only sponges, echinoderms, and ascidians.

indigenous and cryptogenic species, or about $20 \%$ of the totals of $420-585$ species of benthic algae, macroinvertebrates, and fishes observed or collected in these two studies. These proportions substantially exceed values that have been determined for Apra Harbor in Guam (Paulay et al., unpubl. data), where only 46 nonindigenous and cryptogenic species, or about $6.7 \%$, were listed for a total of 682 sponges, echinoderms, ascidians, and other invertebrate species. This nonindigenous component, dominated by hydroids and ascidians (Lambert 2002, Paulay et al. in press), was substantially lower for Guam as a whole. Surveys around Guam indicated only 80 , or $1.7 \%$, of a total of 4635 invertebrate taxa unidentified islandwide (Paulay et al. in press). Of these, only 16 nonindigenous or cryptogenic species were found to occur on coral reefs or other areas outside Apra Harbor. Comparably low nonindigenous percentages have been found for surveys of four North Queensland, Australia, ports where all major taxonomic groups were evaluated and only 1 to $2 \%$ of the $400-600$ species found were considered to be nonindigenous or cryptogenic by the criteria utilized by the investigators (Hewitt et al. 1998, Hoedt et al. $2000,2001)$. Hewitt (2002), in a comparison of nonindigenous species occurring in Australian ports, found a significant increase in introduced species going from tropical to temperate environments, with approximately eight new introductions occurring with each 10 degrees of latitude.

Results for the three nonindigenous species surveys that have been conducted on coral reef areas in the Hawaiian Islands indicate similarly low proportions of nonindigenous species. Only 4 out a total of 444 species, or $1.5 \%$, were nonindigenous in a 1997 survey conducted in the small harbor and reefs of Midway Atoll (Figure 2a; DeFelice et al. 1998), and only three nonindigenous fishes were found on a survey around Kaho'olawe Island in 1998 (Figure 2b; Coles et al. 1998), or $1 \%$ of a total of 298 species found. The latter is a somewhat biased result, because fishes were not systematically surveyed in the Kaho'olawe study and their inclusion would have reduced the nonindigenous percentage even further. From the beginning of its use as a bombing range by the U.S. Navy since the early 1950 s, Kaho'olawe had been isolated from the rest of the Hawaiian Islands, which may in part explain the lack of nonindigenous invertebrates and algae. Likewise, Midway is at the most remote location in the Hawairan 
chain and, although utilized by the U.S. Navy up until the late 1990 s, it still received little ship traffic that could have provided a vector for introduction of marine species. The results from these two isolated areas, which suggest that invasions of nonindigenous species in tropical regions on the coral reefs are not numerous or invasive, may therefore be atypical. However, only one nonindigenous hydroid, two cryptogenic polychaetes, three cryptogenic and one nonindigenous bryozoan species, and three nonindigenous ascidians have been determined out of 668 taxa identified for a survey recently conducted at Johnston Atoll (Coles et al. 2001). This finding is surprising, because of the proximity of Johnston to Hawai $i$, a history of high vessel traffic and human impact, and monthly visits by a supply barge from Honolulu on which specimens of the nonindigenous barnacle Chtbamalus proteus (Southward et al. 1998) have been observed (S.L.C., pers. obs.).

These findings of generally lower rates of species introduction into tropical compared with temperate regions have led to a developing paradigm (Coles et al. 1999b, Hutchings et al. 2002) of tropical areas being less susceptible to marine pest invasions, perhaps due to the more diverse tropical communities offering fewer opportunities for introduced organisms to occupy and compete in their new habitats on arrival (Hutchings et al. 2002). However, this proposed resistance does not necessarily apply to all coral reef areas. Findings of recent surveys in Kāne'ohe Bay, O'ahu, Hawai'i, and Waikīki may be of greater significance for coral reef areas that are more likely to be exposed to nonindigenous species introductions or may offer environmental conditions more amenable to the survival and propagation of introduced organisms. Observations of the Waikiki reef (S.L.C., pers. obs.) indicate it to be highly degraded and overwhelmingly dominated by blooms of the introduced algae Gracilaria salicomia and Acanthophora spicifera along with the native algae Ulva reticulata nearshore and Dictyopteris australis offshore. In contrast with this exposed reef, Kāne'ohe Bay is the largest embayment in Hawai' $i$, with a substantial history of urban impact (Smith et al. 1981) and multiple uses.
It contains three recreational boat harbors and two docking areas for small U.S. Navy vessels at the Kanne'ohe Marine Base, and it receives substantial runoff from the Kāne'ohe Bay watershed. Its habitats include introduced mangroves, inshore mud flats, and coral reefs occurring in both sheltered and oceanic environments. It therefore provides a wide variety of environments that might be utilized by nonindigenous species within diverse shallow marine and brackish-water communities.

Figure 3 shows the numbers of introduced macroalgae, macroinvertebrates, and fishes that were observed in surveys conducted at 25 stations in Kāne'ohe Bay from November 1999 to January 2000. These results include only species that could be identified while diving and are known to be nonindigenous or cryptogenic (Table 4). The list is therefore highly preliminary and will be increased substantially by identifications and analysis being completed on preserved samples. Nevertheless, the results indicate a substantially greater number of introductions than were found at Midway, Kaho'olawe, or Johnston Atoll. A total of 22 nonindigenous and two cryptogenic species (four algae, 17 invertebrates, and three fishes) was observed at the 25 stations. The distribution of these reports indicates the influence of both habitat and proximity to likely locations of introduction. The greatest number occurred on and around a metal structure ("Floating City") that has been in place for about $25 \mathrm{yr}$ in the southcentral sector of the bay. Other areas showing relatively high numbers were mostly located near the bay shoreline and on artificial structures such as metal or concrete pier pilings and near harbor areas at $\mathrm{He}^{6}$ eia in midbay, and in the south bay at the Kanne'ohe Yacht Club and the Marine Base dock.

\section{CASE STUDIES OF TROPICAL NONINDIGENOUS SPECIES}

In contrast to algal species that have become nuisance invaders of many Hawaiian reefs (Russell 1992, Smith et al. 2002) and three species of introduced fishes that are abundant through most of the main Hawaiian islands (Randall 1987), most of the nonindigenous 

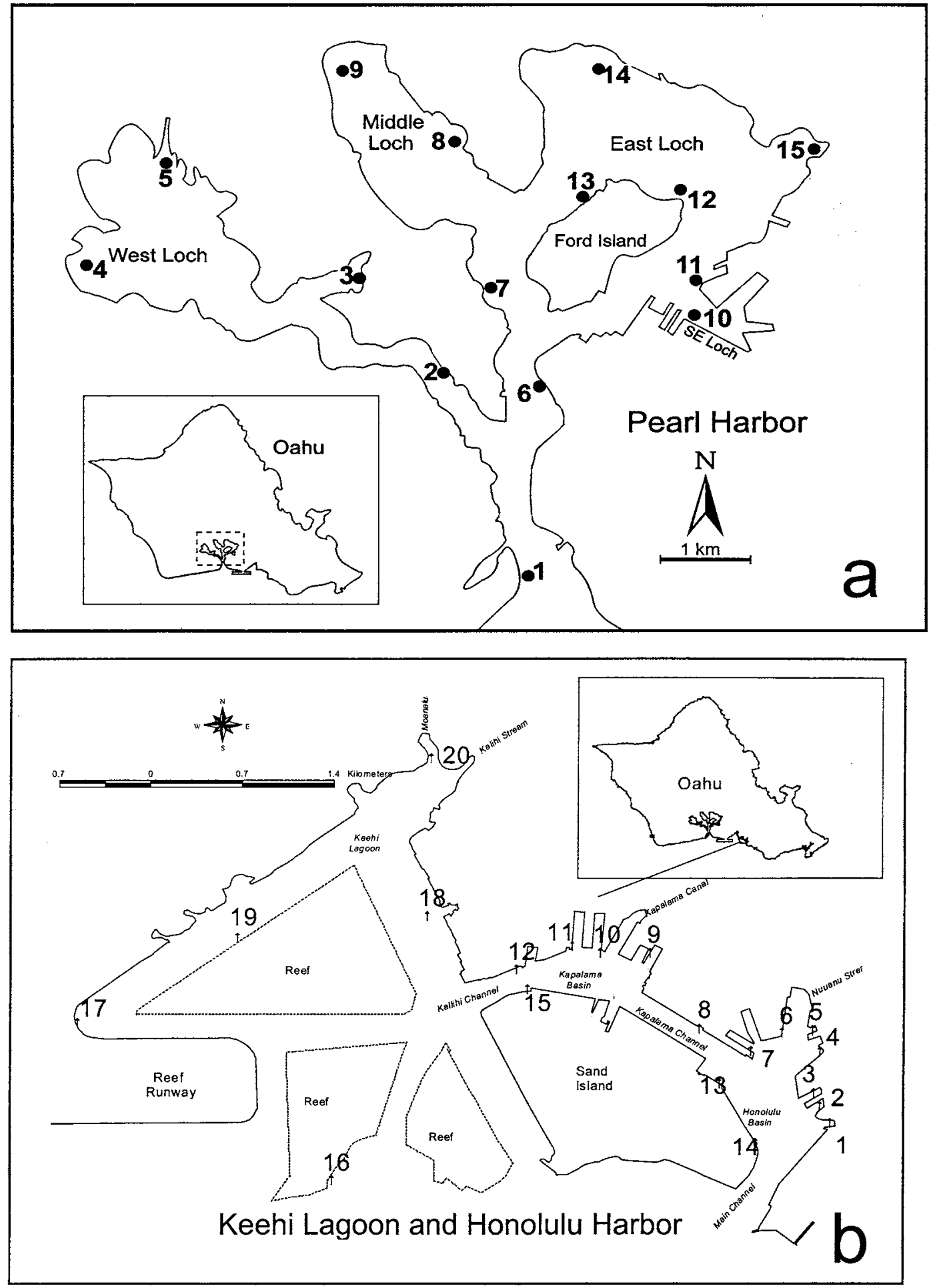

Figure 1. Locations of nonindigenous sampling sites on O'ahu's south and west shores: $a$, Pearl Harbor; $b$, Honolulu Harbor and Ke'ehi Lagoon; $c$, Kewalo Basin and Ala Wai Yacht Harbor; $d$, Barbers Point Deep Draft Harbor. 

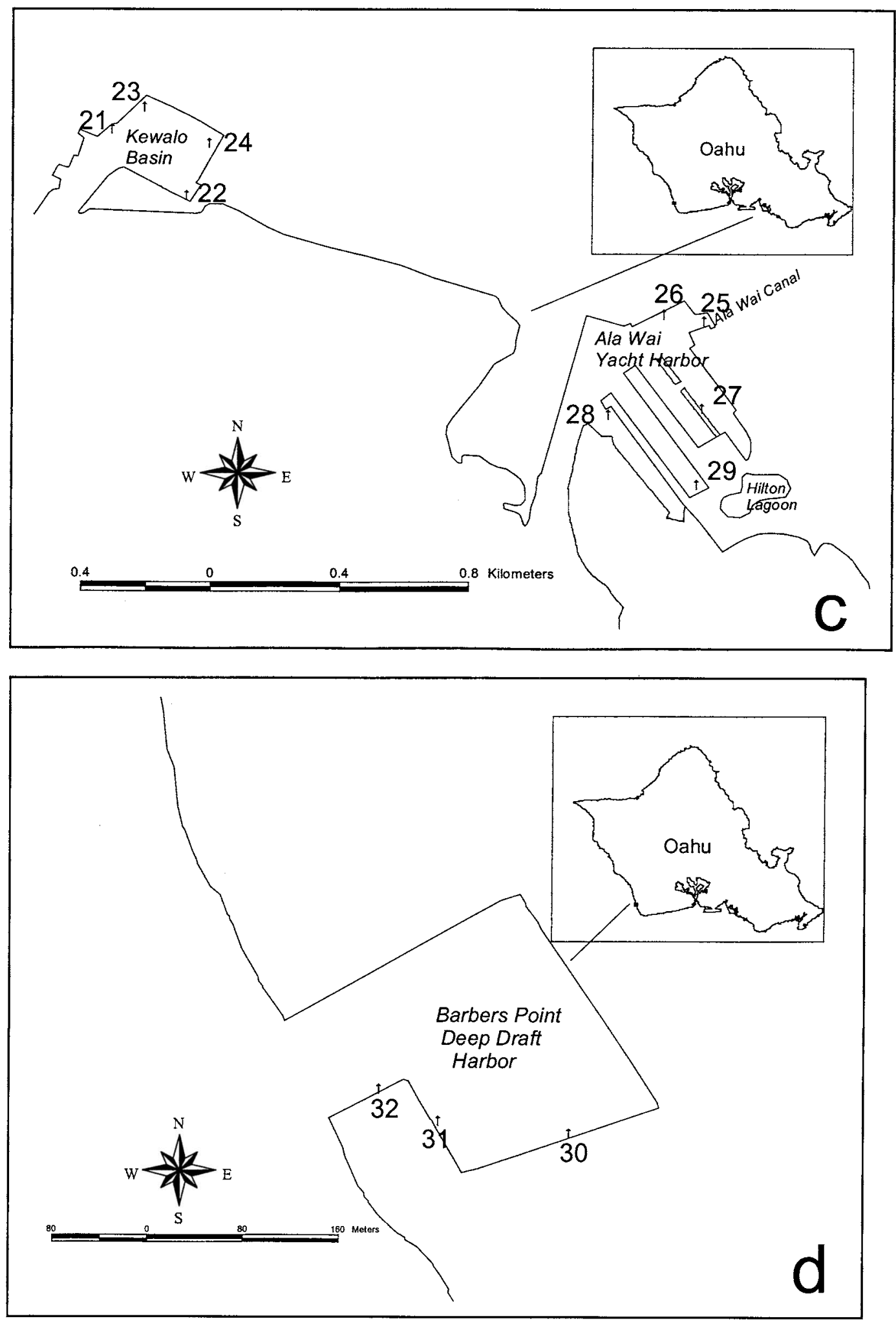

Figure 1. (continued) 

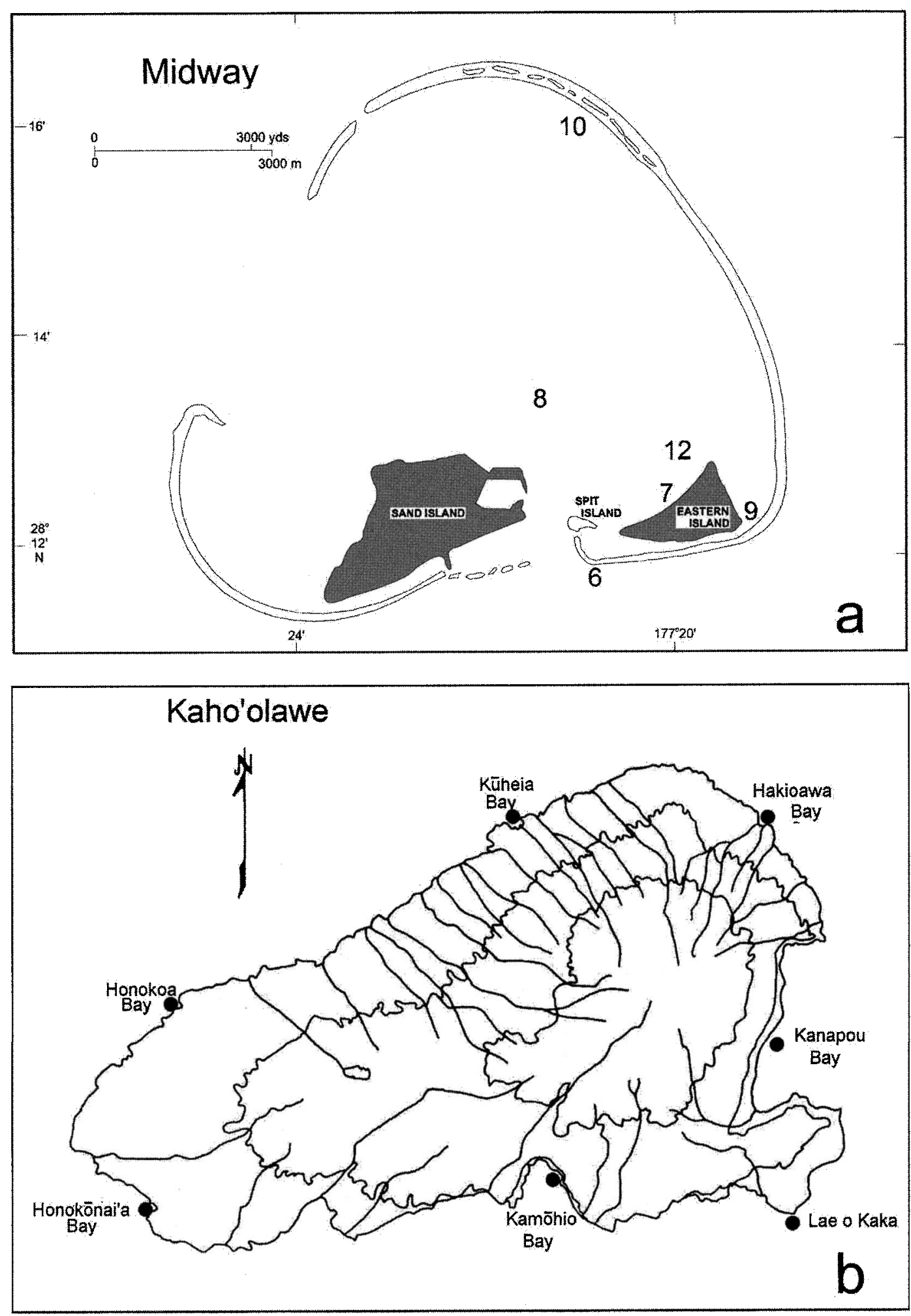

FIgure 2. Locations of sampling sites: $a$, Midway Atoll; $b$, Kaho'olawe Island. 


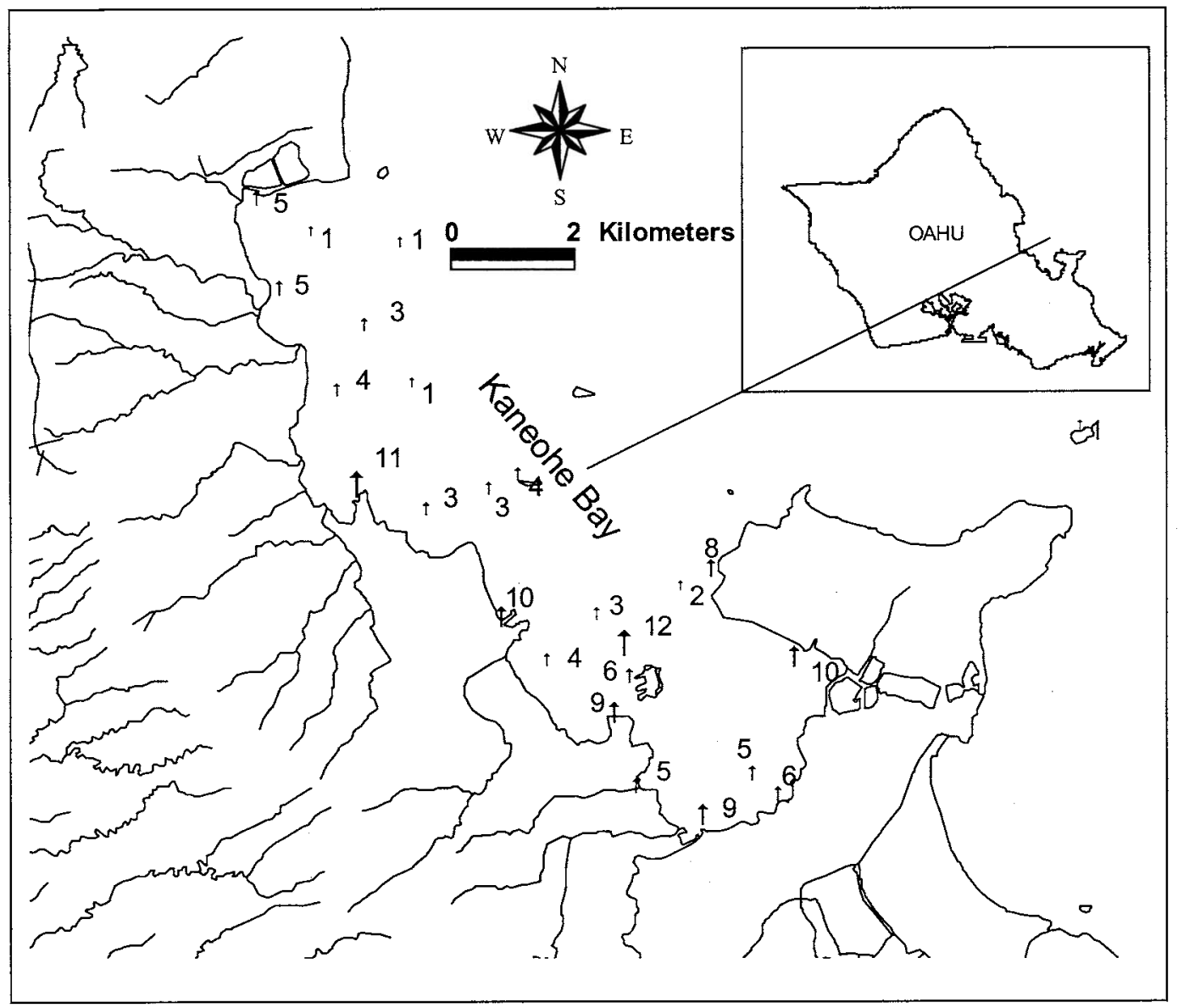

FIGURE 3. Numbers of nonindigenous and cryptogenic species counted at each of 25 stations in Kāne'ohe Bay, O'ahu, Hawai $i$, during visual surveys in 1999-2000.

invertebrate organisms that have been detected in Hawai'i are found almost entirely in harbors or embayments. These areas have a quite predictable community of nonindigenous invertebrates in the fouling community on hard surfaces, composing about $20 \%$ of the total harbor biota by species (Coles et al. $1997,1999 a, b)$. With the exception of Kàne'ohe Bay, few nonindigenous invertebrates have been detected on reefs outside harbors, and these in relatively low abundance (Coles et al. 1998, DeFelice et al. 1998; S.L.C., R. C. DeFelice, and L.G.E., unpubl. data). Only four instances have been well documented where nonindigenous invertebrate species have recently arrived on coral reefs and in tropical waters and proliferated to where they were abundant and invasive. These are the stomatopod Gonodactylaceus falcatus (Manning \& Reaka, 1981); the barnacle Chtbamalus proteus Dando \& Southward, 1980; the dreissenid bivalve Mytilopsis (Congeria) sallei (Recluz, 1849); and the octocoral Carijoa riisei (Duchassaing \& Michelotti, 1864).

\section{Gonodactylaceus falcatus}

Gonodactylaceus falcatus is a stomatopod common in coral rubble in Hawai' $i$ that was described by Manning and Reaka (1981) as 


\section{TABLE 4}

Nonindigenous Species Observed on Surveys in Kāne'ohe Bay, November 1999-January 2000

\begin{tabular}{|c|c|c|c|}
\hline Phylum/Class & Family & Species & $\begin{array}{l}\text { First Hawai }{ }^{4} \mathrm{i} \\
\text { Report }\end{array}$ \\
\hline \multirow[t]{4}{*}{ Rhodophyta } & Gracilariaceae & Gracilaria salicomia (C. Agardh) Dawson & 1971 \\
\hline & Rhodomelaceae & Acanthopbora spicifera (Vahl, 1802) & 1952 \\
\hline & Solieriaceae & Kappapbycus alvareziit? (Doty) & 1974 \\
\hline & Gigartinaceae & Hypnea musciformis (Wulfen) J. Ag. & 1974 \\
\hline \multirow[t]{3}{*}{ Porifera } & Callyspongiidae & Callyspongia diffusa (Ridley, 1884) & 1947 \\
\hline & Mycalidae & Mycale cecilia de Laubenfels, 1936 & 1947 \\
\hline & Niphatidae & Gelloides fibrosa (Wison, 1925) & 1996 \\
\hline \multirow[t]{2}{*}{ Cnidaria } & Pennariidae & Pennaria disticha (Goldfuss, 1820) & 1929 \\
\hline & Telestidae & Carijoa riisei (Duchassaing \& Michelotti, 1860) & 1972 \\
\hline \multirow[t]{4}{*}{ Polychaeta } & Chaetopteridae & Cbaetopterus sp. & 1976 \\
\hline & Sabellidae & Pomatleios kraussi (Baird, 1865) & 1967 \\
\hline & Sabellidae & Sabellastarte spectabilis (Grube, 1878) & 1976 \\
\hline & Serpulidae & Salmacina dysteri (Huxley, 1855) & 1935 \\
\hline \multirow[t]{2}{*}{ Crustacea } & Balanidae & Balanus cf. ampbitrite Darwin, 1854 & 1915 \\
\hline & Chthamalidae & Chtbamalus proteus Darbo \& Southward, 1980 & 1996 \\
\hline \multirow[t]{2}{*}{ Molllusca } & Vermetidae & Eulates tulipa (Chenu, 1843) & 1972 \\
\hline & Ostreidae & Crassostrastrea cf. gigas Thunberg, 1793 & 1926 \\
\hline \multirow[t]{2}{*}{ Ectoprocta } & Vesiculariidae & Amatbia distans Busk, 1886 & 1935 \\
\hline & Schizoporellidae & Schizoporella sp. & 1935 \\
\hline \multirow[t]{2}{*}{ Ascidiacea } & Pyuridae & Herdmania palida or H. insolita (= H. momus Savigny) & ? \\
\hline & Ascidiidae & Pballusia nigra Savigny, 1816 & ? \\
\hline \multirow[t]{3}{*}{ Osteichthyes } & Lutjanidae & Lutjanus fulvus (Bloch \& Schneider, 1801) & 1956 \\
\hline & Lutjanidae & Lutjanus kasmira (Forsskăl, 1775) & 1956 \\
\hline & Cichlidae & Oreocbromis mossambicus (Peters, 1852) & 1952 \\
\hline
\end{tabular}

a new species, Gonodactylus aloba. Previously this stomatopod had been reported by Kinzie (1968) as Gonodactylus falcatus (Forsskål, 1775), an introduced species originally described from the Red Sea and not found in Hawai' $i$ before 1954. Kinzie (1968) proposed that the more aggressive, nonindigenous Gonodactylus falcatus had come to Hawai'i from the Philippines on concrete barges at the end of World War II and had displaced the native stomatopod Pseudosquilla ciliata (Fabricius, 1787) from coral rubble habitats in Hawai'i where $P$. ciliata had formerly dominated. Manning and Reaka (1981) argued that this stomatopod was a previously undescribed endemic species that had gone unreported because of its rarity and that it had become more abundant because of expansion of its population into an increasingly dead coral habitat, especially in Kāne'ohe Bay. They proposed that it had not displaced $P$. ciliata, which was primarily adapted for a sandy rather than a rubble habitat. Kinzie (1984) responded with a detailed set of arguments that questioned the validity of the new species designation instead of $G$. falcatus and substantiated the nonoccurrence of this stomatopod before the 1950s. Moreover, Kinzie (1984) proposed that even if this were a new species, it could be an exotic form that had a greater probability of being detected in its area of introduction than where it was native, particularly if the area of introduction lacked restrictive factors that prevented it from proliferation. Therefore Kinzie proposed "cryptogenic" to be an appropriate designation for this species until its taxonomic identity and relationship with other stomatopods was clarified.

Erdmann (1997) showed that the color differences used by Manning and Reaka (1981) to separate Gonodactylus aloba from Gonodactylus falcatus were within the range of color variation for Gondactylaceus mutatus from Indonesia. Recent work by Barber and Erdmann (2000) using mitochondrial DNA analysis proposed that Gonodactylus aloba is a junior 
synonym of Gondactylaceus mutatus, which has a previously reported range from the western Indian Ocean to New Caledonia. However, more recently Ahyong (2001) synonymized Gondactylaceus mutatus with Gondactylaceus falcatus and supported its designation as a species introduction in Hawai'i. In Hawai' $i$, it has been reported in Kāne'ohe Bay (Kinzie 1968, Reaka 1975, 1976, 1979a,b, Grovhoug and Rastetter 1980, Manning and Reaka 1981), Pearl Harbor (Evans et al. 1974, Grovhoug and Rastetter 1980, Brock 1995, Coles et al. 1997, 1999a), and Honolulu Harbor, Ke'ehi Lagoon, Kewalo Basin, the Ala Wai Yacht Harbor, and Barbers Point Deep Draft Harbor (Coles et al. 1999b).

Following Ahyong (2001) and J. T. Carlton and L.G.E. (unpubl. data) we consider this stomatopod to be an introduction to Hawaiian coral reefs under its original name Gondactylaceus falcatus. If, as appears likely, it is truly introduced, it is the only example currently known in which a nonindigenous invertebrate has displaced a native species, Pseudosquilla ciliata, from its habitat on a coral reef. Both $P$. ciliata and $G$. falcatus still occur on reefs in Kāne'ohe Bay, but semiquantitative samples from recent surveys indicate that $G$. falcatus outnumbers $P$. ciliata by more than 100 to 1 (S.L.C., R. C. DeFelice, and L.G.E., unpubl. data).

\section{Chtbamalus proteus}

Chtbamalus proteus is a small barnacle that lives in the upper subtidal and is native to the Caribbean, Gulf of Mexico, and Brazil (Southward et al. 1998). It was first reported in Hawai'i in 1995 from Kāne'ohe Bay by J. Hoover while preparing his book on Hawaiian marine invertebrates (Hoover 1998) and by Coles et al. (1997, 1999a) from surveys conducted in Pearl Harbor. This species was not present when Matsuda (1973) surveyed barnacles around O'ahu in 1972-1973, nor was it was reported in Pearl Harbor from a comprehensive survey of harbor biota conducted in 1971-1973 (Evans et al. 1974). Chtbamalus proteus therefore arrived in $\mathrm{Ha}-$ wai'i sometime between the mid-1970s and mid-1990s. It is now the most abundant or- ganism in the upper intertidal in harbors and bays throughout the main Hawaiian Islands, and it occurs as far west as Midway and Guam (Southward et al. 1998). Although not strictly a coral reef organism, it does occur in Kāne'ohe Bay and other semienclosed areas that support reef corals and reef biota. Its main requirement for settlement and survival appears to be low water turbulence, and it reaches very high densities on hard surfaces in harbors. It does not seem to have competitively excluded any organism, because the upper intertidal zone in Hawai'i is generally quite barren. However, in areas of intermediate turbulence, such as at the entrance to Kahalui Harbor on Maui, it can compete with the native Hawaiian and commercially valuable limpets Cellana spp. (R. DeFelice, pers. obs.).

\section{Mytilopsis (Congeria) sallei}

The black-striped mussel Mytilopsis (Congeria) salle $i$ is native to the western Atlantic coast of Central America and believed to have entered the Pacific after the opening of the Panama Canal in 1914 (Pyne 1999). In late March 1999 this species was observed in Cullen Bay Marina and later in two other marinas and on vessels in Darwin, Australia, at densities up to $26,350 / \mathrm{m}^{2}$ (Willan et al. 2000) by researchers conducting surveys for the Darwin Port Authority in support of a ballast water risk assessment. It is believed that the mussel entered the marina on the hulls of yachts arriving from the Panama Canal in 1998, and a yacht was found with live specimens on its hull in nearby Frances Bay Marina (Pyne 1999). Fortunately, because of the high tidal exchange, the marinas are isolated from open waters by locked gates, and a rapid response was mounted to eradicate the introduced mussels. This involved the enactment of emergency legislation to permit the use of over 260 tons of liquid sodium hypochlorite and nine tons of copper sulphate, over 280 people including 28 divers, and a cost of over $\$ 1.6$ million (Pyne 1999). Posteradication surveys found no live Mytilopsis sallei in any marina or Darwin harbor, but subsequently this species was observed in September 2000 on two In- 
donesian fishing boats quarantined in Darwin Harbor for illegal fishing (Willan et al. 2000). Both boats left without apparent further infestation of the area, but it is probable that this organism is likely to invade Australian waters unless a means of strict quarantine is devised to prevent its entry on pleasure or fishing vessels.

\section{Carijoa riisei}

The octocoral Carijoa riisei was originally described as Telesto rusei (Duchassaing \& Michelotti, 1860) from St. Thomas, Virgin Islands, after which the name was revised to Telesto riisei (Duchassaing \& Michelotti, 1864). This Caribbean species was previously reported to occur from Florida to Brazil growing in dense clusters in fouling communities below the low tide line on pilings (Bayer 1961, Verseveldt 1978).

Carijoa riisei was first reported as a likely introduction to Hawaili in 1972 (as Telesto riisei) from specimens taken in Pearl Harbor (Evans at al. 1974, Devaney and Eldredge 1977). These were identified by D. M. Devaney of the Bishop Museum and identifications were verified by $\mathrm{R}$. T. Rees of the Bodega Marine Laboratory and F. M. Bayer of the Smithsonian Institution U.S. National Museum (Thomas 1979). Carijoa riisei was originally reported to be common in harbor fouling communities, but by 1979 it was also noted at eight sites on coral reefs around O'ahu from Koko Head to Hale'iwa (Thomas 1979) and later at the entrance to the Ala Wai boat harbor and at Püpūkea, O'ahu (Baker and Scheuer 1994). Recently, sport divers have reported it outside harbors throughout the main Hawaiian Islands at numerous sites around Kaua'i, O'ahu, Maui, Lāna'i, Molokini, and the island of Hawai' $i$ (pers. comm. to S.L.C.). It commonly occurs in caves and under ledges along O'ahu's North Shore from Waimea Bay to Ka'ena Point, where it often reaches high growth densities (S.L.C., pers. obs.).

The available information suggests that Carijoa riisei has spread well beyond Hawai' $i$ into the Indo-Pacific, and that it may have occurred in other Pacific areas before it was first observed in Hawaici. Ross and Scheuer (1979) and Baker and Scheuer (1994) reported collecting it in shallow water off dock pilings at Enewetak Atoll in 1976 and mentioned a nudibranch feeding on colonies of Telesto in Papua New Guinea (Baker and Scheuer 1994). An unidentified octocoral very similar to $C$. riise $i$ is common on oil platforms in the Arabian Gulf, and a close-up photograph of this organism taken in the early 1970 s is shown in Biotopes of the Western Arabian Gulf (Basson et al. 1977:147). Lyanage and Schmitz (1996) reported on $T$. riisei specimens collected at Chuuk Atoll, and specimens identified by $\mathrm{K}$. Muzik as C. trichostema were collected from Chuuk in 1992 (J. Starmer, pers. comm.). Unidentified Carijoa specimens kindly provided by J. Starmer were collected in 1993 to 1999 from Palau, the Philippines, Pohnpei, Fiji, Tonga, and Mauritius. Inspection of skeletal spicules from all of these specimens and comparison with $C$. riisei from Honolulu Harbor and Kāne'ohe Bay indicates no differences among them (S.L.C., pers. obs.), and their spicules closely resemble those diagrammed for Telesto riisei by Bayer (1961). It is interesting that this species was not seen on any of the Northwestern Hawaiian Islands from Nihoa to Kure in a comprehensive survey conducted in October 2000 (R. DeFelice, pers. comm.).

This summary of information points out the need for a thorough systematic comparison of Carijoa riisei reported from the Pacific with specimens obtained from the Caribbean, using both traditional and molecular techniques such as DNA analysis. If specimens are verified to be $C$. riisei throughout the Indo-Pacific, the following research questions pertain: (1) What were the vectors for C. riisei's transport? (2) What were the pathways for its movement through the Pacific? (3) Does this species represent a model by which other more invasive nonindigenous organisms may spread to coral reefs and disturb native populations?

Carijoa riisei appears to be a relatively benign introduction that is occupying previously underutilized habitat and producing no recognized negative impacts on the overall reef community. In this respect it appears to 
TABLE 5

CRIMP Sampling and Analysis Protocols (Adapted from Hewett and Martin 1996)

I. Nonindigenous target species
A. Dinoflagellates
1. Sediment sampling and cyst germination
2. Plankton sampling and culture
3. Analysis for saxotoxin with HPLC
B. Trapping for Carcinus meanas
C. Visual searches for Carcinus meanas, Asterias amurensis, Undaria pinnatifida, Sabella spallanzinii

II. Nontarget species

A. Zooplankton sampling

B. Hard substrate fouling surveys

1. Conducted on wharf piles; breakwaters, seawalls, natural reefs, wrecked vessels, and mariculture facilities

a. Quantitative sampling and photographs of $3 \times 0.10 \mathrm{~m}^{2}$ quadrats

b. Video-recorded transect of piling/facing from surface to bottom

C. Soft substrate surveys

1. Sessile epibenthos

a. Video-recorded 50-m transect

2. Mobile epibenthos

a. Roller beam trawl sampling

3. Benthic infauna adjacent to wharves, piles, or channel markers

D. Fish a. $0.025 \mathrm{~m}^{2} \times 200-250 \mathrm{~mm}$ depth hand corers

1. Rotenone poison stations

2. $25 \mathrm{~m} \times 15 \mathrm{~mm}$ beach seines

III. Environmental data

A. Temperature-salinity-turbidity data logger

B. Sediment sampling and particle size analysis

C. Sediment organic content

IV. Analysis and information storage
A. Processing, preserving, and identification of samples obtained in Activities II.A, II.B.1.a, II.C.3.a, and II.D.1 and 2
B. Archiving of all data
C. Development and maintaining of voucher collection
D. 35-mm slide and video archiving
V. Report preparation

be similar to the barnacle Chthamalus proteus. However, the rapid proliferation of both species suggests that equally fast growing and far more damaging introductions could occur at any time. Along with enhanced vigilance to prevent introductions that may occur from shipping, aquaculture, and marine ornamentals, there is a need for environmental surveys to develop knowledge of baseline conditions and detect nonindigenous introductions. Early detection, such as occurred when the black-striped mussel Mytilopsis sallei was found in the 1999 survey of marinas in Darwin, Australia, in time for its eradication (Pyne 1999), can enable actions that prevent spread of potentially devastating invaders to coral reefs.

\section{SAMPLING APPROACHES TO \\ NONINDIGENOUS SURVEYS}

Nonindigenous surveys conducted to date in the Tropics have been done primarily by two different research groups with similar goals but somewhat different approaches. The more comprehensive approach, called the CRIMP protocol (Hewitt and Martin 1996), was developed by the Centre for Research on Introduced Marine Pests for surveys in temperate Australian ports. This methodology is being utilized in surveys of North Queensland ports, including those that have been completed at Hay Point, Mourilyan Harbour, and Abbot Point (Table 2). The methodology is outlined in Table 5. An alternative 
TABLE 6

BPBM Sampling and Analysis Protocols

I. Field

A. Diving observations

- Record common macrobenthos and fishes

B. Hard substrate fouling

- Selectively sample epibenthic biota from surfaces or chiseled reef substratum, total volume ca. 6-8 liters/ station

- Photograph dominant epibenthic macrobiota

C. Soft substrate infauna

D. Sample 1 sediment core/station $12.5 \mathrm{~cm}$ diameter by $15 \mathrm{~cm}$ deep adjacent to wharves or piles

E. Preserve in $70 \%$ ethanol, or for selected hydroids, actiniarians, polychaetes, and ascidians relax in $\mathrm{MgSO}_{4}$ solution before preservation

II. Laboratory

A. Sieve samples through $0.5-\mathrm{mm}$ mesh screen, re-preserve in $70 \%$ ethanol

B. Sort and identify to species or lowest level practicable

C. Confirm or refine identifications by taxonomic authorities

D. Catalog and archive voucher specimens

E. Prepare database of identifications

III. Literature and museum

A. Query Bishop Museum catalog listings

B. Search published and unpublished literature for previous species reports

IV. Analysis

A. Combine all information in a relational database

B. Determine and assign nonindigenous/cryptogenic/native status

C. Query for first report date, origin, or previous distribution

V. Report preparation

approach to nonindigenous species sampling is shown in the protocol used by Bernice P. Bishop Museum (BPBM) research staff in sampling O'ahu's harbors and reefs (Table 6).

The CRIMP protocol is the more comprehensive and rigorous approach and would be the better choice for researchers with a high level of funding support and a large field and support staff. The CRIMP program also focuses on zooplankton and potentially toxic dinoflagellates that could be spread in ballast water, organisms that were beyond the scope of the BPBM program. The BPBM studies were conducted by only two researchers doing the field observations, sampling, and most of the identifications of specimens, with the assistance of one technician sorting samples to major taxonomic groups and the generous contributions of taxonomic experts in identification and designation of species in regard to nonindigenous status. Further advantages have been having the Bishop Museum collections available as a resource for verifying species identifications and having the inverte- brate database collection (http://www.bishop. hawaii.org/bishop/invert/invertdata.html) and checklist of Hawaiian marine invertebrates (Eldredge and DeFelice 2001) available to establish dates of first occurrence of species in Hawai'i.

\section{CONCLUSIONS AND RECOMMENDATIONS}

The available information suggests that, with the exception of marine algae in Hawai $i$, nonindigenous species are still relatively rare on coral reefs in the Pacific and have not produced the substantial negative impacts that have been caused in many temperate areas. However, large numbers of nonindigenous species occur in O'ahu's harbors, Waikīkī, and Kāne'ohe Bay, indicating that under the appropriate environmental conditions, marine pest invasions can and do occur on or near coral reefs. The rapid movement throughout the Pacific that has occurred for Chthamalus proteus and is suggested for Carijoa riisei, and the near invasion of Mytilopsis sallei into Aus- 
tralian waters indicate that spread and propagation of nonindigenous species warrant concern for and additional studies of marine introductions on coral reefs throughout the tropical Pacific. Virtually nothing is known about marine introductions outside of $\mathrm{O}^{6} \mathrm{ahu}$, Guam, and Australia, and areas near major shipping hubs in the Tropics such as Suva, Fiji, or in the Caribbean are of particular interest. The BPBM protocol is a relatively low-cost approach that can be utilized by any organization with researchers familiar with the local biota and some experience with simple field and laboratory techniques, and this approach can be supplemented with procedures from the CRIMP protocol as determined by the researchers on site. Sampling and surveys should begin as soon as possible and continue throughout the Tropics to establish baselines and document current and future impacts of nonindigenous species on coral reefs.

\section{Literature Cited}

Ahyong, S. T. 2001. Revision of the Australian stomatopod Crustacea. Rec. Aust. Mus. Suppl. 26:1-326.

Allen, G. R. 1991. Field guide to the freshwater fishes of New Guinea. Christensen Research Institute No. 9. Madang, Papua New Guinea.

Allison, A., S. E. Miller, and G. M. Nishida. 1995. Hawai'i Biological Survey: A model for the Pacific region. Pages 349-355 in J. E. Maragos, M. N. A. Peterson, L. G. Eldredge, J. E. Bardach, and H. F. Takeuchi, eds. Marine and coastal biodiversity in the tropical island Pacific region. East-West Center, Honolulu.

Andrews, S. 1985. Aquatic species introduced to Fiji. Domodomo 3:67-82.

Baker, B. J., and P. J. Scheuer. 1994. The punaglandins: 10-chloroprostanoids from the octocoral Telesto riisei. J. Nat. Prod. (Lloydia) 57:1346-1353.

Barber, P. H., and M. E. Erdmann. 2000. Molecular systematics of the Gonodactilidae (Stomatopoda) using mitochondrial cytochome oxidase C (subunit 1) DNA sequence data. J. Crustacean Biol. 20:20-36.

Basson, P. W., J. E. Burchard Jr., J. T. Hardy, and A. R. G. Price 1977. Biotopes of the western Arabian Gulf. ARAMCO Department of Loss Prevention and Environmental Affairs, Dharhan, Saudi Arabia.

Bayer, F. M. 1961. The shallow-water Octocorallia of the West Indian Region: A manual for marine biologists. Martinus Nijhoff, The Hague.

Behrens Yamada, S., C. Hunt, and N. Richmond. 1999. The arrival of the European Green Crab Carcinus meanas in Oregon estuaries. First Natl. Conf. on Marine Bioinvasions, MIT, Cambridge, Massachusetts (abstract).

Bellan-Santini, D., P. M. Arnaud, G. Bellan, and M. Verlaque. 1996. The influence of the introduced tropical alga Caulerpa taxifolia on the biodiversity of the Mediterranean marine biota. J. Mar. Biol. Assoc. U. K. 76:235-237.

Bourdouresque, C. F., A. Meinesz, A. Verlaque, and M. Knoepffler-Peguy. 1992. The expansion of the tropical algae Caulerpa taxifolia in the Mediterranean. Cryptogam. Algol. 13:144-145.

Brock, R. E. 1995. An analysis of benthic communities in the zone of mixing for the Waiau Electrical Generation Facility. Hawaiian Electric Co. Inc., Rep. No. JA619, Honolulu.

Brock, V. E. 1960. The introduction of aquatic animals into Hawaiian waters. Int. Rev. Gesamten Hydrobiol. 45:463-480.

Buttermore, R. E., E. Turner, and M. G. Morrice. 1994. The introduced northern Pacific seastar Asterias amurensis in Tasmania. Mem. Queensl. Mus. 36:21 -25.

Carlton, J. T. 1985. Transoceanic and interoceanic dispersal of coastal marine organisms: The biology of ballast water. Oceanogr. Mar. Biol. Annu. Rev. 23:313371.

. 1993. Biological invasions and biodiversity in the sea: The ecological and human impacts of nonindigenous marine and estuarine organisms. Pages 5-11 in Nonindigenous Estuarine and Marine Organisms (NEMO), Proceedings of the Conference and Workshop. Government Printing Office No. 0208-C-04, Seattle, Washington. 
1996. Biological invasions and cryptogenic species. Ecology 77:1653-1655.

Carlton, J. T., and J. B. Geller. 1993. Ecological roulette: The global transport of nonindigenous marine organisms. Science (Washington, D.C.) 261:78-82.

Carlton, J. 'T., J. K. Thompson, L. E. Schemel, and F. H. Nichols. 1990. Remarkable invasion of San Francisco Bay (California, USA) by the Asian clam Potamocorbula amurensis. 1. Introduction and dispersal. Mar. Ecol. Prog. Ser. 66:81-94.

Chu, K. H., P. F. Tam, C. H. Fung, and Q. C. Chen. 1997. A biological survey of ballast water in container ships entering Hong Kong. Hydrobiologia 352:201-206.

Cohen, A. N. 1999. Status of invasions and policy response on the U.S. west coast. First Natl. Conf. on Marine Bioinvasions, MIT, Cambridge, Massachusetts (abstract).

Cohen, A. N., J. T. Carlton, and M. C. Fountain. 1995. Introduction, dispersal and potential impacts of the green crab Carcinus meanas in San Francisco Bay, California. Mar. Biol. (Berl.) 122:225-237.

Coles, S. L., R. C. DeFelice, L. G. Eldredge, and J. T. Carlton. 1997. Biodiversity of marine communities in Pearl Harbor, Oahu, Hawaii with observations on introduced species. Bishop Mus. Tech. Rep. No. 10.

Coles, S. L., R. C. DeFelice, J. E. Smith, D. Muir, and L. G. Eldredge. 1998. Determination of baseline conditions for introduced marine species in nearshore waters of the island of Kaho'olawe, Hawaii. Bishop Mus. Tech. Rep. No. 14.

Coles, S. L., R. C. DeFelice, L. G. Eldredge, and J. T. Carlton. 1999a. Historical and recent introductions of non-indigenous marine species into Pearl Harbor, Oahu, Hawaiian Islands. Mar. Biol. (Berl.) 135:147-158.

Coles, S. L., R. C. DeFelice, and L. G. Eldredge. 1999b. Nonindigenous marine species introductions in the harbors of the south and west shores of Oahu, Hawaii. Bishop Mus. Tech. Rep. No. 15.

Coles, S. L., R. C. DeFelice, and D. Minton. 2001. Marine species survey of Johnston
Atoll, Central Pacific Ocean, June 2000. Bishop Mus. Tech. Rep. No. 19.

DeFelice, R. C., S. L. Coles, D. Muir, and L. G. Eldredge. 1998. Investigation of the marine communities of Midway Harbor and adjacent lagoon, Midway Atoll, Northwestern Hawaiian Islands. Bishop Museum, Hawaiian Biological Survey Contrib. No. 1998-014, Honolulu.

Devaney, D. M., and L. G. Eldredge. 1977. Subclass Octocorallia. Pages 119-129 in D. M. Devaney and L. G. Eldredge, eds. Reef and shore fauna of Hawaii. Section 1: Protozoa through Ctenophora. Bishop Museum Press, Honolulu.

Duchassaing, P., and J. Michelotti. 1860. Memoire sur les coralliaires de Antilles. Mem. R. Accad. Sci. Torino 19:279-365.

1864. Supplement au memoire sur les coralliaires de Antilles. Mem. R. Accad. Sci. Torino 23:97-206.

Eldredge, L. G. 1987. Coral reef alien species. Pages 215-228 in B. Salvat, ed. Iuman impacts on coral reefs: Facts and recommendations. Antenne Museum EPHE, Papeete.

. 1994. Introductions of commercially significant aquatic organisms to the Pacific Islands. Perspectives in Aquatic Exotic Species Management in the Pacific Islands. South Pac. Reg. Environ. Program Rep. Studies 78:1-127.

. 2000. Non-indigenous freshwater fishes, amphibians and crustaceans of the Pacific and Hawaiian Islands. Pages 173190 in G. Sherley, ed. Invasive species in the Pacific: A technical review and draft regional strategy. South Pacific Regional Environmental Programme, Apia.

Eldredge, L. G., and R. C. DeFelice. 2001. Checklist of the Hawaiian marine invertebrates (http://www2.bishopmuseum.org/ HBS/invert/list_home.htm). Bishop $\mathrm{Mu}$ seum, Honolulu.

Erdmann, M. E. 1997. The ecology, distribution and bioindicator potential of Indonesian coral reef stomatopod communities. Ph.D. diss., University of California, Berkeley.

Evans, E. C., III, N. L. Buske, J. G. Grovhoug, E. B. Guinther, P. L. Jokiel, D. T. 
O. Kam, E. A. Kay, T. J. Peeling, and S. V. Smith. 1974. Pearl Harbor biological survey-Final report. Naval Undersea Center Rep. No. NUC TN 1128. San Diego.

Godwin, L. S., and L. G. Eldredge. 2001. South Oahu marine invasions shipping study (SOMISS). Bishop Mus. Tech. Rep. No. 20.

Grosholz, E., and G. Ruiz. 1999. The impacts of the European green crab on multiple trophic levels in central California. First Natl. Conf. on Marine Bioinvasions, MIT, Cambridge, Massachusetts (abstract).

Grovhoug, J. G., and E. B. Rastetter. 1980. Marine fouling dynamics in Hawaii nearshore ecosystems: A suggested technique for comparison and evaluation. Pages 249266 in Proc. 5th Int. Congr. on Mar. Corrosion and Fouling, Madrid.

Hewitt, C. L. 2002. Distribution and biodiversity of Australian tropical marine bioinvasions. Pac. Sci. 56:213-222.

Hewitt, C. L., and R. B. Martin. 1996. Port surveys for introduced marine speciesbackground considerations and sampling protocols. CSIRO Cent. Res. Introduced Mar. Pests Tech. Rep. 4:1-40.

Hewitt, C. L., M. L. Campbell, K. M. Moore, N. B. Murfet, and B. Robertson. 1998. Introduced species survey. Port of Hay Point, Queensland. CSIRO Centre for Research on Introduced Marine Pests (CRIMP) Report to Ports Corporation of Queensland, Brisbane.

Hilliard, R. W., P. A. Hutchings, and S. Raaymakers. 1997. Ballast water risk assessment for 12 Queensland ports, Stage 4: Review of candidate risk biota. Ecoports Monogr. Ser. No. 13.

Hoedt, F. E., J. H. Choat, J. Collins, and J. J. Cruz. 2000. Mourilyan Harbour and Abbot Point surveys: Port marine baseline surveys and surveys for introduced marine pests. School of Marine Sciences and Aquaculture, James Cook University Report to Ports Corporation of Queensland, Brisbane.

2001. Port of Lucinda surveys: Port marine baseline surveys and surveys for introduced marine pests. School of $\mathrm{Ma}$ - rine Sciences and Aquaculture, James Cook University to Ports Corporation of Queensland, Brisbane.

Hoover, J. P. 1998. Hawaii's sea creatures. Mutual Publishing, Honolulu.

Hutchings, P. A., R. W. Hilliard, and S. L. Coles. 2002. Species introductions and potential for marine pest invasions into tropical marine communities, with special reference to the Indo-Pacific. Pac. Sci. 56:223-233.

Kinzie, R. A., III. 1968. The ecology of the replacement of Pseudosquilla ciliata by Gonodactylus falcatus (Crustacea: Stomatopoda) recently introduced into the Hawaiian Islands. Pac. Sci. 22:465-475.

1984. Aloha also means goodbye: A cryptogenic stomatopod in Hawaii. Pac. Sci. 38:298-311.

Lambert, C. C., and G. Lambert. 1998. Nonindigenous ascidians in southern California harbors and marinas. Mar. Biol. (Berl.) 130:675-688.

Lambert, G. 2002. Nonindigenous ascidians in tropical waters. Pac. Sci. 56: (in press).

Larson, A., V. Gerard, and R. Cerrato. 1999. Potential impact of the recently introduced Asian Shore Crab, Hemigapsus sanguineus, on the rocky intertidal communities of the northern U.S. coast. First Natl. Conf. on Marine Bioinvasions, MIT, Cambridge, Massachusetts (abstract).

Lyanage, G. K., and F. J. Schmitz. 1996. Cytotoxic amides from the octocoral $T e$ lesto riisei. J. Nat. Prod. (Lloydia) 59:148151.

Maciolek, J. A. 1984. Exotic fishes in Hawaii and other islands of Oceania. Pages 131161 in W. R. Courtenay and J. R. Stauffer Jr., eds. Distribution, biology and management of exotic fishes. Johns Hopkins University Press, Baltimore.

Manning, R. B., and M. L. Reaka. 1981. Gonodactylus aloha, a new stomatopod crustacean from the Hawaiian Islands. J. Crustacean Biol. 1:190-200.

Matsuda, C. 1973. A shoreline survey of freeliving barnacles (Class Crustacea, Subclass Cirrepedia; Order Thoracia) on the island of Oahu, Hawaii. M.S. thesis, University of Hawai'i at Mānoa, Honolulu. 
McDermott, J. J. 1991. A breeding population of the western Pacific crab Hemigrapsus sanguineus (Crustacea: Decapoda: Grapsidae) established on the Atlantic coast of North America. Biol. Bull. (Woods Hole) 181:195-198.

-1999. A review of the natural history of the Asian Shore Crab Hemigrapsus sanguineus in the western Atlantic with additional information on its biology. First Natl. Conf. on Marine Bioinvasions, MIT, Cambridge, Massachusetts (abstract).

Meinesz, A. 1999. Killer algae: The true tale of a biological invasion. University of Chicago Press, Chicago.

Munro, J. L. 1993. Aquaculture development and environment issues in the tropical Pacific: Environment and aquaculture in developing countries. Pages 125-138 in Proc. Int. Cent. Living Aquat. Resour. Manage. Congr., Manila.

Mutlu, E. 1999. Distribution and abundance of ctenophores and their zooplankton food in the Black Sea. II. Mnemiopsis leidyi. Mar. Biol. (Berl.) 135:603-613.

Nelson, S. G., and L. G. Eldredge. 1991. Distribution and status of introduced cichlid fishes of the genera Oreocbromis and Tilapia in the islands of the South Pacific and Micronesia. Asian Fish. Sci. 4:11-22.

Paulay, G., L. Kirkendale, G. Lambert, and C. Meyer. In press. Anthropogenic biotic interchange in a coral reef ecosystem: A case study from Guam. Pac. Sci.

Pyne, R. 1999. The black striped mussel (Mytilopsis sallei) infestation in Darwin: A clean-up strategy. Ecoports Monogr. Ser. No. 19:77-83.

Randall, J. E. 1987. Introductions of marine fishes to the Hawaiian Islands. Bull. Mar. Sci. 41:490-502.

Reaka, M. L. 1975. Molting in stomatopod crustaceans. I. Stages of the molt cycle, setagenesis, and morphology. J. Morphol. 146:55-80.

1976. Lunar and tidal periodicity of molting and reproduction in stomatopod crustacea: A selfish nerd hypothesis. Biol. Bull. (Woods Hole) 150:468-490.

- 1979a. Patterns of molting frequencies in coral-dwelling stomatopod crusta- cea. Biol. Bull. (Woods Hole) 156:328342.

1ife 1979b. The evolutionary ecology of life history patterns in stomatopod crustacea. Pages 235-260 in S. E. Stancyk, ed. Reproductive ecology of invertebrates. University of South Carolina Press, Columbia.

Rodriguez, L. F., G. M. Ruiz, and W. C. Walton. 1999. Where north meets south: Invasion of Tasmania by the European Green $\mathrm{Crab}$ and its consequences for native crabs. First Natl. Conf. on Marine Bioinvasions, MIT, Cambridge, Massachusetts (abstract).

Ross, R. A., and P. J. Scheuer. 1979. 18-Acetoxy and 18-Hydroxpregna-1,4,20-Trien3-one from the telestean octocoral Telesto riisei (Duchassaing \& Michelotti). Tetrahedron Lett. 49:4701-4704.

Ruiz, G. M., J. T. Carlton, E. D. Grosholz, and A. H. Hines. 1997. Global invasions of marine and estuarine habitats by nonindigenous species: Mechanisms, extent, and consequences. Am. Zool. 37:621-632.

Russell, D. J. 1992. The ecological invasion of Hawaiian reefs by two marine red algae, Acanthophora spicifera (Vahl) Boerg. and Hypnea musciformis (Wulfen) J. Ag., and their association with two native species, Laurencia nidifica J. Ag. and Hypnea cervicornis J. Ag. Int. Counc. Explor. Sea Mar. Sci. Symp. 194:110-125.

Seeley, R. H. 1999. History and impact of an intertidal invasion: Green crabs (Carcinus meanas [L.]) in New England, 1900-1998. First Natl. Conf. on Marine Bioinvasions, MIT, Cambridge, Massachusetts (abstract). Shushkina, E. A., G. G. Nikolaeva, and T. A. Lukasheva. 1990. Changes in the structure of the Black sea planktonic community at mass reproduction of sea gooseberries Mnemiopsis leidyi (Agassiz). Oceanology 51:54-60.

Smith, J. E., C. L. Hunter, and C. M. Smith. 2002. Distribution and reproductive characteristics of nonindigenous and invasive marine algae in the Hawaiian Islands. Pac. Sci. 56: (in press).

Smith, L. D., M. J. Wonham, L. D. McCann, G. M. Ruiz, A. H. Hines, and J. T. Carl- 
ton. 1999. Invasion pressure to a ballastflooded estuary and an assessment of inoculant survival. Biol. Invasions 1:67-87.

Smith, S. V., W. J. Kimmerer, E. A. Laws, R. E. Brock, and T. W. Walsh. 1981. Kaneohe Bay sewage diversion experiment: Perspectives on ecosystem responses to nutritional perturbation. Pac. Sci. 35:279-395.

Southward, A. J., R. S. Burton, S. L. Coles, P. R. Dando, R. DeFelice, J. Hoover, E. Parnell, T. Yamaguchi, and W. A. Newman. 1998. Invasion of Hawaiian shores by an Atlantic barnacle. Mar. Ecol. Prog. Ser. 165:119-126.

Thomas, W. J. 1979. Aspects of the microcommunity associated with Telesto riisei, an introduced alcyonarian species. M.S. thesis, University of Hawai'i at Mānoa, Honolulu.

Thompson, J., and S. Luoma. 1999. Food web and contaminant flow effects of an exotic bivalve in San Francisco Bay. First Natl. Conf. on Marine Bioinvasions, MIT, Cambridge, Massachusetts (abstract).

Uwate, K. R., B. Kunatuba, B. Raobati, and C. Tenakani. 1984. A review of aquaculture activities in the Pacific Islands region. Pacific Islands Development Program, East-West Center, Honolulu.

Verseveldt, J. 1978. On some Telestacea and Alcyonacea (Coelenterata: Octocoral- lia) from the West Indian region. Zool. Meded. (Leiden) 53:41-47.

Vinogradov, M. Y. E., E. A. Shushkina, E. I. Museyava, and P. Y. U. Sorokin. 1989. A newly acclimated species in the Black Sea: The ctenophore Mnemiopsis leidyi (Ctenophora: Lobata). Oceanology 29:220-224.

Walford, L., and R. Wicklund. 1973. Contribution to a world-wide inventory of exotic marine and anandromous organisms. FAO Fish. Tech. Rep. 121.

Werry, L. P. 1998. A review of freshwater fish introductions in Papua, New Guinea. Sci. New Guinea 24:33-38.

West, G. J., and J. Glucksman. 1976. Introduction and distribution of exotic fish in Papua New Guinea. Papua New Guinea Agric. J. 27:19-48.

Willan, R. C., B. C. Russell, N. B. Murfet, K. L. Moore, F. R. McEnnulty, S. K. Horner, C. L. Hewitt, G. M. Dally, M. L. Campbell, and S. T. Bourke. 2000. Outbreak of Mytilopsis sallei (Recluz, 1849) (Bivalvia: Dreissenidae) in Australia. Molluscan Res. 20:25-30.

Wonham, M. J., J. T. Carlton, G. M. Ruiz, and L. D. Smith. 2000. Fish and ships: Relating dispersal frequency to success in biological invasions. Mar. Biol. (Berl.) 136:1111-1121. 